\title{
The Mechanisation and Automation of the IBS Construction Approach in Malaysia
}

\author{
Siti Syariazulfa Kamaruddi ${ }^{1}$, Mohammad Fadhil Mohammad, \\ Rohana Mahbub, Khairani Ahmad
}

Construction Economics and Procurement Research Group, Centre of Studies for Quantity Surveying, Faculty of Architecture, Planning \& Surveying, Universiti Teknologi MARA (UiTM), 40450 Shah Alam, Selangor, Malaysia.

sitisyariazulfa@yahoo.com

\begin{abstract}
The objective of the main research is to investigate the current state of implementation of mechanisation and automation in the Industrialised Building System (IBS). The aim of this paper however, is to provide an overview on the implementation of mechanisation and automation in the IBS construction approach. Questionnaire survey and semi structured interviews were conducted to collect the viewpoints among contractors and manufacturers of IBS to ensure the richness of the data collected. The results illustrated that although most respondents have agreed on most critical issues in the implementation of mechanisation and automation, they were not ready to move forward. These responses were quite consistent across the professions.
\end{abstract}

Keywords: Modern method of construction (MMC); industrialised building system (IBS); mechanisation and automation; environment.

eISSN 2514-751X @ C 2018. The Authors. Published for AMER ABRA cE-Bs by e-International Publishing House, Ltd., UK. This is an open-access article under the CC BY-NC-ND license (http://creativecommons.org/licenses/bync-nd/4.0/). Peer-review under responsibility of AMER (Association of Malaysian Environment-Behaviour Researchers), ABRA (Association of Behavioural Researchers on Asians) and CE-Bs (Centre for EnvironmentBehaviour Studies), Faculty of Architecture, Planning \& Surveying, Universiti Teknologi MARA, Malaysia DOI: https://doi.org/10.21834/aje-bs.v3i10.324 


\subsection{Introduction}

The construction industry is widely acknowledged for its vital economic role and contribution to countries' GDP. In addition to this economic importance, the construction industry also accounts for a high political, environmental and social profile, which is attributed to its key role in providing housing, its impact on the construction environment, as well as being a major employer.

Industrialised Building System (IBS) is accountable for the significant reduction of wastages and reduction of the consumption of natural resources to preserve our environment. Jaillon et al. (2009) estimated that the average wastage reduction level due to the implementation of IBS is about $52 \%$. As commonly agreed, conventional on-site work normally involves extreme activities on the site that cause constant nuisances to local communities such as messy environment, traffic chaos, noise, and air pollution (Yee, 2001). This is a rather remarkable rate compared to constructions without IBS operation. Therefore, construction practice, methods and material have continuously changed to fulfil nations' needs (Ngowi et al. 2005). The amount of raw material and natural resources used in construction for creating and operating the built environment are estimated to exceed those consumed in any other sector.

In Malaysia, as a result of the governments' initiatives in advancing the use of innovative technologies, the IBS approach is actively promoted through several strategies and incentives as an alternative to conventional building methods. The commitment of the government in encouraging the use of this approach can be seen with the development of the Roadmap IBS 2011-2015 published by the Construction Industry Development Board (CIDB) outlined several well thought strategies and aggressive steps to promote the use of IBS in Malaysia. The Roadmap was aimed to provide a quality, efficient, competent and sustainable IBS that contributes the competitiveness of the Malaysian construction industry.

The IBS can be described as a construction technique where components are manufactured on or off-site, transported and then assembled into a structure with the minimum of work. IBS is also considered as a Modern Method Construction (MMC). MMC is the term used to describe a number of innovations in house building in particular, and construction industry in general, mostly adopting offsite technologies by moving work from the construction site to the factory (Pan et al. 2007). Hence, MMC provides the opportunity for the players in the construction industry to develop a new image of the construction industry to be at par with other manufacturing industries such as the automobile and electronic. Furthermore, there has been a paradigm shift regarding MMC in Malaysia for the past few years whereby the industry has continually embraced new and modern technologies and methods that can increase the quality of its end-product, with faster speed of construction whilst coping with the issues of foreign workers. The Malaysian construction industry has faced unique challenges in practice and image in the past, and it is about time that it should be transformed into a modern and efficient industry.

Therefore, this study aims to provide an overview of the MMC in Malaysia towards the critical issues encountered during the process of implementing the mechanisation and automation approach. This study may complement precedent studies and assist players in 
the construction industry to improve their current approach and practice and deliver better products to end users/customers in the near future. In the end, the research to practice initiative at CIDB is focus on the issues of foreign workers. Among these factors is the transfer and exchange of knowledge, human capital, economic growth, and the use of high technology in the construction industry is one of the ways to achieve the initiative by CIDB. Research to practice is a way of conducting research to help ensure that it is relevant to industry players and results in reducing the use of foreign workers and avoid the problem of social and economic problems.

\subsection{Literature Review}

\subsection{The construction industry in Malaysia}

The construction industry in Malaysia shares $3.2 \%$ of the country's Gross Domestic Product (GDP) in the last quarter of 2010 and employs over 1,000,000 workers. In Malaysia, construction sector plays an important role in generating's economy, with 3 to $5 \%$ of the national GDP contributed by the sector for the past 20 years. Apparently this statistic obviously shows that construction is one of the important major sectors that stimulate our country's economy. Booming construction activities is a warning that the country's economy is in a risk condition while slow-moving construction activities shows a depressed condition (Kamar, 2012). In line with Mahbub (2012) the problems associated with the construction industry such as, decreasing quality and productivity, labour shortages, occupational safety and inferior working condition have highlighted the need for an innovative solution within the industry. Construction industry in Malaysia generally comprises many processes and these include many parties and different stages of work. The concept of using IBS in Malaysia started after the Minister of Housing and Local Government of Malaysia visited several European country. IBS generally includes all building components which are mass produced either in factory or at site. All the components of the building will be designed according to specifications with standardised shapes and dimensions. This is the significant starting point where the IBS becomes more popular in Malaysia. Most of the IBS systems used in Malaysia are large panel systems, steel frame, precast frame and formwork system. All these systems have been largely used for private residential projects in Malaysia which include projects in Shah Alam, Wangsa Maju and Pandan, Dua Residency, KL, Taman Mount Austin and Tongkang Pecah, Johor (CIDB,2006). This demand can be met by means of the advanced technology used in the IBS.

\subsection{Overview of modern method construction (MMC)}

In Malaysia, the phrase "industrial building system" is widely used by the government and by practitioners. IBS is a construction technique in which a building's components are manufactured in a controlled environment (on- or off-site), transported, positioned, and assembled into a structure; only minimal additional work is done on-site (CIDB, 2003). This research studies pattern of $\mathrm{MMC}$ and IBS to overview of $\mathrm{MMC}$ and to investigate the current 
state of implementation of mechanisation and automation approach.

The vital issue on the MMC and IBS has common related drive and attribute constraints that started seriously in early 90's. In Malaysia, the Construction Industry Development Board CIDB have played an important role in changing the paradigm of the construction industry into more knowledgeable, achieving high skills and flexibility of competitive products having the same view as the construction industry in UK and Australia (Blismas et al. 2006, Blismas and Wakefield 2008, Pan et al. 2008, Nadim and Goulding 2009, Majid et al. 2010).

The similarity and obstacle of MMC and IBS is to have a break through to the end user and client's negative perspective of the architectural value as well as to make aware of the construction industry benefits when applying the off-site technology for the long term investment (Azman, 2012). In addition, the government and the financial support play an important role to ensure the policy and regulatory work well with the construction industry especially in training and adequate monetary aid to the small and medium entrepreneur (Kamar, 2012).

There are several definition of modern method construction (MMC). Table 1 illustrates the definition of the MMC. However, it can be simplified that MMC is interrelated concepts of IBS, prefabrication, off site manufacturing (OSM) and off site production (OSP).

Table 1. Definition of modern method construction (MMC)

\begin{tabular}{|c|c|c|c|c|c|c|}
\hline Definitions & $\begin{array}{l}\text { JABE, } \\
2004\end{array}$ & $\begin{array}{l}\text { Burwood } \\
\text { et al. } 2005\end{array}$ & $\begin{array}{l}\text { Bura, } \\
2005\end{array}$ & $\begin{array}{l}\text { Pan et al. } \\
2007\end{array}$ & $\begin{array}{l}\text { Nadim } \\
\text { and } \\
\text { Goulding } \\
2010\end{array}$ & $\begin{array}{l}\text { Azman et } \\
\text { al., } 2011\end{array}$ \\
\hline $\begin{array}{l}\text { MMC enhancement of } \\
\text { quality, reduction of on-site } \\
\text { time, improvement of on- } \\
\text { site safety and addressing } \\
\text { the skilled labour shortage. }\end{array}$ & $\sqrt{ }$ & & & & & \\
\hline $\begin{array}{l}\text { MMC has been described } \\
\text { by various names, such as } \\
\text { 'pre-fabrication', 'off-site } \\
\text { production' and 'off-site } \\
\text { manufacturing' (OSM). }\end{array}$ & & $\sqrt{ }$ & & & & \\
\hline $\begin{array}{l}\text { MMC are the practices of } \\
\text { off-site manufacturing } \\
\text { (OSM), prefabrication } \\
\text { (prefab), industrial building } \\
\text { systems (IBS), and off-site } \\
\text { production (OSP). }\end{array}$ & & & $\sqrt{ }$ & & $\sqrt{ }$ & \\
\hline $\begin{array}{l}\text { MMC is the term used to } \\
\text { describe a number of } \\
\text { innovations in house } \\
\text { building in particular, and } \\
\text { construction industry in } \\
\text { general, most of which are } \\
\text { offsite technologies, } \\
\text { moving work from }\end{array}$ & & & & $\sqrt{ }$ & & \\
\hline
\end{tabular}


construction site to the

factory.

MMC, OSM and IBS have

the interrelated concept of

prefabrication and onsite

fabrication

Sources: CABE, (The Commission for Architecture and the Built Environment) 2004, Burwood et al. 2005, Bura

(British Urban Regeneration Association), 2005, Pan et al. 2007, and Nadim and Goulding, 2010.

From an innovation of view, MMC is one of the means sought to improve and change the construction industry practices through emphasising the manufacturing concept and the introduction of different levels of mechanisation, hence catering for the different modes of innovation (Slaughter, 1998). In this context, MMC is closely intertwined with the concept of industrialising the construction industry (Tatum et al. 1986, Warszawski, 1999; O'Brien et al., 2000; Gibb, 2011; Morton, 2002). Essentially, industrialisation can be seen as a business strategy that transforms the traditional construction process into a manufacturing and assembly process by engaging people, embracing (new) technology and it is argued that OSP may help reduce the amount of labour needed on the job (Gibb, 1999). The main benefits will be high quality products, fast track completion projects, reduced foreign workers and changing the perception of construction industry market into global market chain value. With the intention to adopt the increasingly rapid technological changes, MMC is expected to play a greater role in ensuring improvement in construction activities and sustainable economic growth. This method can effectively save costs and improve the construction quality by reducing labor intensity and construction standardization. Besides, it minimises waste, reduces site material, yields cleaner and neater environment, provides higher quality control, and cuts the total construction costs. Examples of successful implementation of MMC in the world include Sesikui Home (Japan), Living Solution (United Kingdom), Open House (Sweden) and Wenswonen (Netherlands).

Many countries are using MMC on a wider scale, particularly the Scandinavia and Germany. Many of their companies export MMC products/houses, and Japan now builds $40 \%$ of its new houses using MMC (POST 2003). Many other countries have recognised the benefits of MMC, but are not using it widely. The MMC which is widely used in Europe, Japan and Singapore is seen as an alternative option to the Conventional Construction in maintaining sustainability in construction through the efficient use of resources, improvements in the quality of constructed buildings and waste minimisation (Tam et al., 2007; Kibert, 2007; Begum et al., 2010).

\subsection{Implementation of mechanisation and automation}

Azman et al., (2010) in the context of Malaysian construction industry which has currently been transformed into a mass production in developing the standardisation of products in line with the global market. Mechanisation, automation and robotics have been proof of improving the construction process in all aspects. The most popular advantages of the mechanisation in building as mentioned in various literature are: mechanising, robotising and 
automating construction processes can speed up construction as reducing production time also reduces the overall cost (Idoro, 2011; Gassel, 2008; Idrus, 2008; Wakisaka et al. 2000; Marinez et al. 2008; Crowley, 1998). Other than that mechanisation can improve conditions, avoid dangerous work, allow work to be performed that people cannot do (Gassel, 2008). There are five degrees of industrialisation described by Richard (2005). In theory, the degree of industrialisation is shown in Figure 1. They are prefabrication, mechanisation, automation, robotic and reproduction as follow:

1. Prefabrication is a manufacturing process that basically takes place at a specialised facility, in which different materials are joined to form a component part of the final installation.

2. Mechanisation comes in whenever machinery is employed to ease the workload of the labourer.

3. Automation is a situation when the tooling (machine) totally takes over the tasks performed by the labourer.

4. Robotics comprises the ability of the same tooling which has the multi-axis flexibility to perform diversified tasks by itself.

5. Reproduction implies that the research and development of innovative processes is truly capable of simplifying the production process.

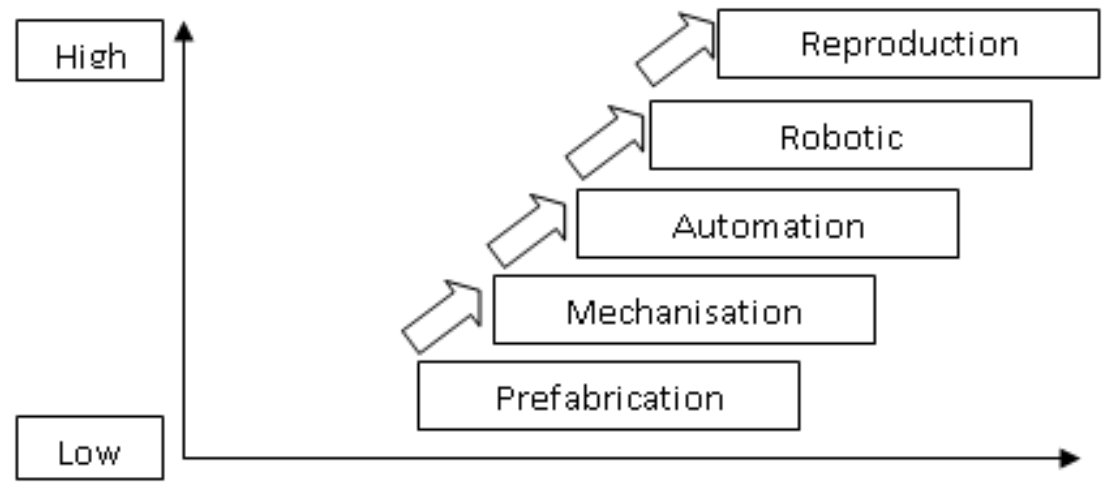

Fig. 1. Degree of industrialisation (Richard, 2005)

According to Richard (2005), the first four degrees are still more under the influence of the traditional methods of building. Prefabrication aims rather at the location on the production where the next three degrees (mechanisation, automation and robotics) aim at substituting labour with machineries (Richard, 2005). This range of this research is in between the mechanisation a bit into the earlier stage of automation implementation on site.

The circumstances in UK construction industry are facing traditional technology that comprise of brick/concrete block cavity wall methods, timber/precast floors and timber truss roofs (Pan et al. 2007). Moreover, the house buyers are strongly influenced by negative perceptions of the MMC innovation in houses construction that will spoil the authentic 
traditional houses (Edge et al. 2002). This has affected the construction industry and the innovative in building technologies are having difficulty to be implemented by industry players (Pan et al. 2007; Ball 1999; Barlow 1999; Roskrow 2004). The UK government came with a solution by introducing the modern method of construction to describe the number of innovations in offsite technologies which can be applied in house building (Gibb, 1999). This is a challenge to adopt the combination of growth demand with poor quality and low productivity that the construction players need a 'step change' in construction techniques and processes (Buildoffsite 2005).

Therefore, the MMC approach has in many aspects proven to become more sustainable in terms of cost, time and quality through the use of prefabrication. However, the value creation of industrialisation can only be enhanced using appropriate mechanization and automation manufacturing processes which are different from the current conventional project. Adopting mechanisation and automation will reduce the construction activities on site to just a simple transport and assembly processes and thus, becomes less complex. Clearly, if Malaysia wished to imitate the success of others developed countries and parallel with the government goal, the industry must move forwards towards the industrialisation of building and construction sector should be pursued (Kamar, 2012).

\subsection{Methodology}

This paper is part of an on-going research on mechanisation and automation in the IBS construction approach in Malaysia which is still at the initial stage, as such the information presented is primarily based on the review of relevant literature on the system. The nature of this research is partly exploratory and attempts to identify the major issues by examining the viewpoints of experts in the construction industry. This would allow critical issues and key factors encountered during the process of implementing the mechanisation and automation approach in the IBS in Malaysia could be addressed in order to assist players in the industry to improve their current approach and practice and deliver better products to end users/customers in the near future.

The study focused on coexisting events and used a representative sample to draw inferences and conclusions without the direct participation of the researcher. The primarily concerned of a research usually deals with the extent rather than the depth of the data, therefore the appropriate method for data collection was conducted by means of a survey (Fellows and Liu 2003). First, a questionnaire was design and developed to gather data relating to the 40 main research questions. The questionnaire included scaled and openended questions because this was felt to be more appropriate for the sample; it allowed for general and specific comments and maintained the interest of the respondents. Second, the questionnaire was mailed to IBS consultants, contractors, manufacturers, and expert academics. It was designed to elicit information from those organizations that had previous experience in IBS construction. 


\subsection{Survey questionnaire}

The questionnaire was designed and developed after a comprehensive review of the literature and a pilot study discussion with sample participants. It was divided into three main parts. The first section gathered general information about the designation and the type organisation. The second part is the overview of MMC or IBS construction approach. The last section presented the implementation of mechanisation and automation.

\subsection{Results and Discussions}

The analysis that is presented is the combination of literature review and results from the preliminary study in the form of exploratory interviews among a panel of experts in IBS in Malaysia. The key results from the interviews are highlighted with the apparent in the mechanisation and automation of the IBS construction approach: a Malaysian experience aspect is presented below.

The semi structured interviews involved putting forward questions examining the respondents' opinion on the key factors that will decide on the use of MMC or IBS construction approach are to resolve the foreign labour workforce issues, improvement on the quality of the project, minimise the volume of material consumed in finishing the projects, and whether it can promote a better perception towards the construction industry where they are known to be dirty, low quality and dangerous. This will also hope to be in accordance with the government policy towards meeting the national agenda or master plan. The government has also encouraged more sustainable investments in the country by providing tax incentives for such developments. Furthermore, the use of IBS components in government projects must not be less than $70 \%$ and the inclusion of IBS as part of contract documents for all new government's building. The government has also imposed a policy to limit the number of foreign workers in Malaysian in addition to other incentives and policies to promote the use of IBS in the country. The percentages (\%) of projects that are being developed using MMC or IBS in Malaysia are still at a moderate stage between $6-10 \%$ which is slower than expected. In line with Hamzah et al., (2010) IBS has not been effectively implemented in Malaysia despite having been first introduced in the late 1960s.

There can be a variety of factors that will influence the implementation of mechanisation and automation in construction with long-term sustainability. Among the factor pertinent to Malaysian would be the reduction of foreign labour, which has become a long standing national issue. According to Hamid et al., (2008), IBS adoption in Malaysian will gradually reduce the dependency on foreign labour thus saving the county's loss in foreign exchange. Therefore, the effective way to reduce the number is to implement a structured and effective mechanisation and automation in the construction process of the IBS.

The barriers of mechanisation and automation in the Malaysian construction industry are still less compared to other developing county although they may not be ready to change and move forward. Its show the industry is familiar with the conventional system and the technology that suits them well and therefore they are unwilling to switch to a mechanised based system and IBS. Hence, the majority of contractors are not keen to adopt 
mechanisation and automation due to their readiness to move forwards (Kamar, 2012).

Among the critical success factors to be considered for new comers who are interested in getting involved in adopting mechanisation and automation include learning from other industries such as the automotive industry or from other neighbouring countries such as Indonesia, Thailand and Singapore. Players must also have the hands on experience with a positive approach including having the long term plan \& vision with the strong believe and determination to change which is the most critical factor that will significantly influence the choice between conventional and IBS construction approach. A government's policy should be imposed on the use of IBS for large developments including greater utilisation of mechanisation and automation.

Finally, the respondents unanimously agreed that there is a bright future and great opportunities for the implementation of mechanisation and automation in the Malaysian construction industry. The use of mechanisation and automation technologies will be cheaper in the long run especially with a greater standardisation of the design and construction process. Some respondents believed that the technologies will enable firms to operate more efficiently and competitively.

\subsection{Conclusions}

There is the need for the Malaysian construction industry to opt for a new and improved construction technique in order to shift from the conventional construction technique to a much more modern method of construction. The introduction of MMC and IBS has certainly made an impact to the industry but so far it has not achieved the level of technology adopted by developed countries especially where mechanisation and automation is concerned. This paper presented the overview of the MMC in Malaysia of the implementation of mechanisation and automation of the IBS construction approach. The result of the research have shown that the establishment of the IBS, MMC and OSM will require all participants to acquire relevant knowledge on the current technology in the construction industry in order to compete globally and be able to adjust to the needs of the current economic changes and demand. However, despite the many key issues that need to be attended, the IBS end product that thrives on quality and durability must be recognised and truly appreciated. This is to address the issues on sub-standards, delays and unacceptable quality of end products normally associated with the traditional method of construction. The industry should also respond and co-operate with the initiative by the government to encourage off-site manufacturing and to embark on research work to increase the standard of the construction industry. The experience and problems faced in setting up off-site manufacturing should be shared and there should also be an exchange of knowledge to motivate and educate other countries to move to a higher level of development for the construction industry. In the end, the good quality and durability of buildings that are delivered to the occupiers will lead them to a better environment. 


\section{Acknowledgement}

The Author is appreciative of the expertise of the supervisory committee and to industry collaborators for their practical and applied evaluations. A remark of indebtedness is also owed to the Research Intensive Faculty (RIF) by the Universiti Teknologi MARA (UiTM), for its grant award.

\section{References}

Azman et al., (2012). Comparative Study on Prefabrication Construction Process, International Surveying Research Journal (ISrJ), 45-58.

Ball, M. (1999). Chasing a snail: innovation and housebuilding firm's strategies. Informaworld, Housing Studies 14:(1) , 9-22.

Barlow, J. (1999). From craft production to mass customisation: innovation requirements for the UK housebuilding industry. Informaworld, Housing Studies 14:(1) , 23-42.

Begum R.A, Satari S.K, Pereira J.J (2010). Waste generation and recycling: comparison of conventional and industrialized building systems. American Journal of Environmental Sciences. 6(4), 383-8.

Burwood, S, Poul, J. (2005). Modern Methods of Construction: evolution or Revolution: A BURA Steering and Development Forum Report. London: British Urban Regeneration Association.

BURA (2005). Modern Methods of Construction: Evolution or Revolution? British Urban Regeneration Association (BURA): Steering and Development Forum, London.

CABE. (2004). Design and modern methods of construction: review. London: CABE.

CIDB (2003). Industrialized Building System (IBS) Roadmap 2003-2010. Construction Industry Development Board (CIDB), Kuala Lumpur.

CIDB (2006). Industrialised Building Systems in Malaysia. CIDB Press.

CIDB (2007). Construction Industry Master Plan (CIMP) 2006-2015, Kuala Lumpur, Malaysia.

CIDB (2010) Industrialised Building Systems (IBS) Roadmap 2011-2015, Construction Industry Development Board (CIDB) Malaysia, Kuala Lumpur.

Gibb, A.G. (1999). Off-site Fabrication - Pre-assembly, Prefabrication and Modularisation, Whittles Publishing Services, Caithness, 262.

Hamzah NH, Nafi MNA, Yacob J, Ashari AH, Daud Z, Sulain AS (2010). A study on the acceptance of IBS in construction industry in Kelantan: application of logistic regression analysis.

Idoro, (2008). Influence of Channels of Recruitment on Performance of Construction Workers in Nigeria. Proceedings of the West Africa Built Environment Research (WABER) Conference 2011 (19-21 July 2011, Accra, Ghana.

Idrus, A., Hui, N.F.K and Utomo, C. (2008). Perception of Industrialized Building System (IBS) Within the Malaysian Market. International Conference on Construction Building Technology (ICCBT), 75-92. 
Jaillon, L., C. S. Poon and Y. H. Chiang. (2009). Quantifying the waste reduction potential of using prefabrication in building construction in Hong Kong. Waste Management 29 (1). 309-320.

Kamar et al. (2007). Industrialised Building System: Current shortcomings and the vital role of R\&D. Master Builders Association Malaysia, 2nd quarter, 62-65. Malaysia Construction Research Journal, 2 (1), 20-25.

Kamar, K,A, M, Hamis, Z,A and Dzulkalnine, N (2012). Industrialised Building System (IBS) Construction: Measuring the perception of Contractors in Malaysia.

Kibert C, J. (2007). The next generation of sustainable construction. Building Research \& Information. 35(6). 595601.

Mahbub, R. (2012). Readiness of a Developing Nation in Implementing Automation and Robotics Technologies in Construction: A Case Study of Malaysia. Civil Engineering and Architecture, USA. 6(7).

Morton, R. (2002). Construction UK: Introduction to the Industry, Blackwell Science, Oxford.

Ngowi, A.B., Pienaar, E., Talukhaba, A. and Mbachu, J., (2005). The globalization of the construction industry- a review, Building and Environment 40, 135-141.

Nadim, W. and Goulding, J.S. (2009). Offsite production in the UK: the way forward? A UK construction industry perspective, Emerald, Construction Innovation,10, 181-202.

O'Brien, M., Wakefield, R. and Beliveau, Y. (2000). Industrializing the Residential Construction Site, Center for Housing Research, Virginia Polytechnic Institute and State University, Blacksburg, V.

Pan, W., Gibb, A.G. F., and Dainty, A. R. J. (2007). Perspectives of UK house builders on the use of offsite modern methods of construction. Construction Management and Economics, 25, 183-194.

Richard, R. B. (2005). Industrialised Building Systems: Reproduction Before Automation And Robotics, Automation In Construction, 14 (2005), 442- 451.

Roskrow, B. (2004). Design and deliver. Housebuilder pp. 18-20. — September.

Slaughter, E.S., (1998). Models of construction innovation. Journal of Construction Engineering and Management, 124(3), 226-232.

Tam V.W.Y, Tam C.M, Zeng S.X, Ng W.C.Y (2007). Towards adoption of prefabrication in construction. Building and Environment. 42(10). 3642-54.

Warszawski, A. (1985). Industrialised and Automated Building Systems. Technion-Israel Institute of Technology,E and FN Spoon.

Warszawski, A. (1999).Industrialised and automated building systems. Technion-Israel Institute of Technology, E and FN Spon.

Yee, A. A. 2001. Social and environmental benefits of precast concrete technology. PCI Journal 5-6. 14-20. 